\title{
Feeding ecology of blue rock pigeon (Columba livia) in the three districts of Punjab, Pakistan
}

\author{
F. Batool (D), H. A. Khan ${ }^{a *}$ (ID) and M. Saif-ur-Rehman ${ }^{b}$ \\ ${ }^{a}$ Department of Zoology, Wildlife and Fisheries, University of Agriculture, Faisalabad, Pakistan \\ 'Institute of Animal and Dairy Sciences, University of Agriculture, Faisalabad, Pakistan \\ *e-mail: druafhammad@yahoo.com
}

Received: June 21, 2019 - Accepted: August 29, 2019 - Distributed: November 30, 2020

(With 4 figures)

\begin{abstract}
Present paper provides information on the feeding regimens of the two genders of the blue-rock pigeon (Columba livia Linn.) in the sampled habitats of the three districts viz. Rawalpindi, Faisalabad and Bahawalpur of the Punjab province, Pakistan. This feral pigeon, considered ubiquitous species, inhabits both the grasslands and clumped environments to establish their roosts and nests. The study explored about comparable feeding proportions from three major habitats of the pigeons which were captured with medium sized mist-nets. For Rawalpindi in the winter season, the Zea mays was one of the predominant food item (30.6\%) for males, and other ranked major food contents were $(26.7 \%, 22.4 \%$ and $20.2 \%)$, and fairly similar feeding proportions were also recorded for the females $(50.4 \%, 33.3 \%, 36.4 \%$ and $23.9 \%)$ for Carthamus oxyacantha, Hordeum vulgare, Triticum aestivum and Zea mays respectively. Evidently, no significant deviations in the existing food crops for the three sites for the feral pigeon were detected, which strongly suggested that the, modes of feeding habits among the sustainable roosts and nests which were closely located to food crops, exerted negligible impacts during intermittent pigeon foraging movements in the diurnal conditions.
\end{abstract}

Keywords: blue-rock pigeon, foraging, regimes, crops, Punjab.

\section{Ecologia de alimentação do pombo-da-rocha-azul (Columba livia) nos três distritos de Punjab, Paquistão}

\section{Resumo}

O presente artigo fornece informações sobre os regimes de alimentação dos dois sexos do pombo-da-rocha-azul (Columba livia Linn.) nos habitats amostrados dos três distritos, a saber: Rawalpindi, Faisalabad e Bahawalpur, da província de Punjab, Paquistão. Este pombo-doméstico, considerado espécie onipresente, habita tanto as pastagens quanto os ambientes agrupados para estabelecer seus poleiros e ninhos. O estudo explorou proporções comparáveis de alimentação de três grandes habitats dos pombos que foram capturados com redes de neblina de tamanho médio. Para Rawalpindi no inverno, Zea mays foi um dos itens alimentares predominantes (30,6\%) para os machos, e outros alimentos classificados como principais foram $(26,7 \% ; 22,4 \%$ e $20,2 \%)$, e proporções bastante semelhantes foram registradas para as fêmeas $(50,4 \%, 33,3 \%, 36,4 \%$ e 23,9\%) para Carthamus oxyacantha, Hordeum vulgare, Triticum aestivum e Zea mays, respectivamente. Evidentemente, não foram detectados desvios significativos nas culturas alimentares existentes nos três locais para o pombo-doméstico, sugerindo fortemente que os modos de alimentação entre os poleiros e ninhos sustentáveis, que estavam estreitamente localizados em culturas alimentares, exerceram impactos não significativos durante os períodos intermitentes dos movimentos de forrageamento dos pombos-domésticos nas condições diurnas.

Palavras-chave: pombo-da-rocha-azul, forrageamento, feeding regimens, culturas, Punjab.

\section{Introduction}

Feral pigeon (Columba livia Linn.) inhabits various habitats viz. crevices in buildings, holes in water pipes, small dumps in aquatic channels, bare-rock cliffs, and domestic gardens and household vents (Roberts, 1991; Sacchi et al., 2002; Lever, 1987; Haag-Wackernagel, 1991). It is also named as the rock dove with its antecedents present in the coastal areas of Ethiopian region and lately in the Indian sub-continent (Goodwin, 1983). Such wild populations, therefore, appear to provide the domestic pigeon strains due to artificial selection (Sossinka, 1982; Maan and Chaudhry, 2001). In the rural and urban surroundings, pigeons are present in the light vegetation, few of the agricultural crops, farm-yards, feed mills and parks in varying numbers (Williams and Corrigan, 1994; Burgman and Lindenmeyer, 
1998; Angold et al., 2001). Majority of the pigeons are considered 'granivorous' and are closely associated with human habitations due to their domestic origin and the biological characteristics (Baldaccini, 1996). In the past few decades, the rock dove population has increased due to occurrence of sufficient availability of the abandoned food in the both rural and urban environments and the stored grain structures. They also inhabit the seedling stages of some crops throughout the year (Sims, 1979; Haag-Wackernagel, 1994; Haag-Wackernagel and Moch, 2004; Sol and Senar, 1995; Soldatini et al., 2006).

Feral rock-dove populations inflict serious health problems to humans due to their sporadic dropping in man-made buildings, stored grain structures, few roosting sites of birds', and, therefore, interfere directly with natural ecological systems, and cause parasitic infections to man (Haag-Wckernagel et al., 2006). Pathogens are directly transmitted to man through pigeon excreta, secretions, and the dust shed off directly from their feathers (Curtis et al., 2002). According to Gallo et al. (1989), proportions of yeasts affecting the feral pigeons in the rural habitats ranged from $7 \%$ to $22 \%$, and the commonly found pathogens to impact humans were Chlamydo phillapsittaci and Cryptococcus neoformans, while incidence of Salmonella was rare (Haag-Wackernagel and Moch, 2004). Several feral pigeons, therefore, remain important source of vectors of both parasites and pathogens in closeinteraction with animals (Bevan, 1990; Pedersen et al., 2006; Sol and Price, 2008).

Several populations of rock-dove also cause considerable aircraft problem with their direct varying flocks'strikes close to the runways. On the ground, their dropping cause slips and trips in the buildings and external passages (Cleary et al., 2006; Dolbeer et al., 2000). Blue rock pigeon may also destroy the original architectural and structural designs to variety of buildings due to their tenacious activities as the construction of either temporary or permanent roosts and nests for sufficient periods (Ballarini et al., 1989; Pimental et al., 2000). Large communal flocks present close to the pathways of crops can also damage the food crops due to their continuous diurnal foraging activities for about three to eight $\mathrm{km}$ per day (Johnston and Janiga, 1995; Baldaccini et al., 2000; Soldatini et al., 2006; Hetmanski et al., 2010). Therefore, feeding proportions appear to vary with respect to crop type, crop stage, habitat and pigeon population (Saini and Toor, 1991; Van Niekerk and Van Ginkel, 2004). Zucconi et al. (2003) reported on the data from the large city avenues in Italy and suggested that that the overall costs of cleaning the city streets and squares, augmented only $3 \%$ pigeon populations, while may increase to about (10-15\%) in the abandoned and old historical buildings for the similar habitat.

Reliable population studies and management measures for the rock-dove are frequently estimated by the 'quadrat counts' (QC) and 'correction factor' (CF). Both of them are based on the mark and recapture methods in both short and wide habitats (Senar, 1996; Sacchi et al., 2002). Management of feral pigeon also largely relies on the pigeon-man interactions in various ecosystems.
Importantly, all such approaches should be calibrated on the assumption that they remain ecologically acceptable and without any risk factors to ecosystem sustainability (Canover, 2002). Presently, eco-friendly approaches emphasize on a) culling; b) inhibited reproductive success; and c) reduction in habitat fitness. For the monogamous rock-dove, with considerable rates of productivity, may also suffer the mortality rates. For this, possible culling appears less effective than to inhibit their population size (Dolbeer, 1998; Younas and Yaqoob, 2005). Nonetheless, culling has been extended for feral pigeons in some habitats, but without sufficient success percentage (Feare, 1991; Johnston and Janiga, 1995; Sol and Senar, 1995). Decreased reproductive success involves the removal and puncturing of pigeon eggs from their nests, and replaces them with the decoy eggs for various rural and urban environments. Nonetheless, its limited success has also been observed particularly in overwhelming communal roosts owing to unfavourable intrinsic demographic factors (Feare, 1991; Kautz and Malecki, 1991). Therefore, decreased habitat fitness with some carrying capacity appears reliable method to inhibit their roosts and nests in both rural and urban habitats (Haag-Wackernagel, 1993). Limitations to the food sites and nesting may perhaps be achieved conveniently through application of exclusion method or bird deterring techniques with the mechanical repellents (Haag-Wackernagel, 2000; Seamans et al., 2007), and impacts of acoustic, chemical and visual repellents may last only for short duration (Haag-Wackernagel, 2000; Haag-Wackernagel and Geigenfeind, 2008). Objective of the present study was, therefore, to assess the seasonal variations in feeding regimens of the blue rock pigeon, based on its food preference for the both genders, in the three major districts of Punjab, Pakistan.

\section{Material and Methods}

This study was conducted in the three major provinces of Punjab (Pakistan) for period of 16 months to determine the detailed the feeding regimens of the feral pigeon (Columba livia).

\subsection{Important avifauna of three districts}

\subsubsection{Faisalabad}

Faisalabad is mainly considered agricultural landscape comprising variety of crops and plantations grown annually. Therefore, there appears no dearth of food limitation here which triggers important point for the various species of insect and vertebrate pests to thrive well, cause damage and economic losses to the economically important crops. Of the birds' fauna, different species of various orders have been recorded. Some of them are native, while others are also exotic (largely winter visitors) emerging from cold parts of Europe and Siberia.

\subsubsection{Rawalpindi}

Rawalpindi is named as twin city with that of Islamabad, capital city of Pakistan. Both are separated by distance of about $15 \mathrm{~km}$. It is also considered largely educational with 
several colleges and universities besides comprising the Ayubia Wildlife Park and the thick 'Pothawar Plataue' with sufficient numbers of birds. As such, there remains fairly large assemblage of birds throughout the year.

\subsubsection{Bahawalpur}

This district is located in the Northern hemisphere of the Punjab province. It has ancient history of traditional empire of the Muslim communities before the war of freedom (1857) before overtaken by the British rulers, till gaining the independence in 1947 as province of Pakistan. This city has modern cantonment areas with spacious Lal Suhanra Wildlife Park along the beautiful water channel. There is, therefore, invariably enriched diversity of birds, native, winter visitors and frequent.

\subsubsection{Capture of pigeon}

For the present investigations, blue rock pigeons were directly trapped from one acre crop fields using medium sized mist nets. Nets were erected longitudinally and were held together by the medium wooden bamboos (three on each side). In all, for each field, two mist nets were installed closer to the food crops in the evening. Examination for the captured pigeons was determined in the following morning. Trapped birds placed in large polyethylene bags and were brought to the laboratory for further analysis.

\subsubsection{Assessment of food diversity}

Analysis for the gut contents of the captured pigeons was made with the body weight on the standard digital balance. Each rock-dove was subsequently fixed in the dissecting tray with cotton swabs and dissected dorso-ventrally with the sharp needles. Detailed crop and gizzard analysis of the birds was made in $10 \%$ formaldehyde dipped cotton threads. After the analysis was over, cotton threads were dried (using thick tissues) to eliminate any of the moisture contents and examined food contents were appropriately labelled to ascertain the bird preference. Extracted food materials were later placed in the clean petri-dishes which were present with the identical grids on the sufficiently large identical grids. Overall relative frequency percentage of various food contents removed was determined as Equation 1:

Relative frequency $(\%)=\frac{\text { Total contents of a specimen }}{\text { No. of contents analyzed }} \times 100$

\subsubsection{Statistical analysis}

Data was statistically analyzed using the multivariate two-way simple correspondence analysis (SCA) to determine the category-wise variables and classification (Minitab 17-version) for the preference of dietary constituents of the blue rock pigeon in different seasons sampled from three major habitats of Punjab (Steel et al., 1997).

\section{Results and Discussion}

Present study was extended for period of 16 months (January 2016 through April, 2017) in the three districts viz. Rawalpindi, Faisalabad and Bahawalpur of Punjab, Pakistan to determine the food preferences (Tables 1, 2 and 3) for the male and female blue rock pigeon. Table 4 presents proportions of feeding by the male rock-doves of the occurring ten food items in the row profile.

\subsection{Rawalpindi}

In Rawalpindi, for the male rock-dove, Zea mays remained intensively depredated food item (Table 4) for all four viz. fall, spring, winter and summer with percentages $30.6 \%$, $26.7 \%, 22.4 \%$ and $20.2 \%$ and were followed by the Hordeum vulgare $(48.0 ; 43.6 ; 32.7$ and 18.8$)$. The least consumed food items were the unidentified animal and plants. For the

Table 1. Occurrence of some common birds in Faisalabad.

\begin{tabular}{ccc}
\hline Scientific name & Order & Frequency of occurrence \\
\hline Acridotheres tristis & Passeriformes & $\mathrm{N}$ \\
Psittacula krameri & Psittacidae & $\mathrm{N}$ \\
Passer domesticus & Passeriformes & $\mathrm{N}$ \\
Corvus splendens & Passeriformes & $\mathrm{N}$ \\
Columba livia & Columbiformes & $\mathrm{F}$ \\
Parus major & Passeriformes & $\mathrm{W}$ \\
Pycnonotus cafer & Passeriformes & $\mathrm{F}$ \\
Copsychus saularis & Passeriformes & $\mathrm{W}$ \\
Motacella flavi & Passeriformes & $\mathrm{N}$ \\
Riparia riparia & Passeriformes & $\mathrm{N}$ \\
Athene noctua & Strigiformes & $\mathrm{F}$ \\
Tyto alba & Strigiformes & $\mathrm{N}$ \\
Accipeter nisus & Accipiteriformes & $\mathrm{F}$ \\
Milvus migrans & Accipiteriformes & $\mathrm{N}$ \\
Falco irideus & Falconiformes & $\mathrm{N}$ \\
\hline
\end{tabular}

$\mathrm{F}=$ frequent; $\mathrm{N}=$ native; $\mathrm{W}=$ winter visitor. 
Table 2. Common occurring birds of Rawalpindi.

\begin{tabular}{ccc}
\hline Scientific name & Order & Frequency of occurrence \\
\hline Tachybapus rufficollis & Podicepidiformes & $\mathrm{W}$ \\
Nycticorax nycticorax & Pelecaniformes & $\mathrm{W}$ \\
Corvus splendens & Passeriformes & $\mathrm{N}$ \\
Tyro alba & Strigiformes & $\mathrm{F}$ \\
Passer domesticus & Passeriformes & $\mathrm{N}$ \\
Anseriformes & Anseriformes & $\mathrm{F}$ \\
Bubulcus ibis & Ciconiformes & $\mathrm{N}$ \\
Ardeola greyii & Ciconiformes & $\mathrm{N}$ \\
Egretta garzetta & Ardeidae & $\mathrm{W}$ \\
Ardea purpurea & Ardeidae & $\mathrm{W}$ \\
Anas strepera & Anseriformes & $\mathrm{F}$ \\
Anas crecca & Anseriformes & $\mathrm{F}$ \\
Athene brama & Strigiformes & $\mathrm{N}$ \\
\hline
\end{tabular}

$\mathrm{F}=$ frequent; $\mathrm{N}=$ native; $\mathrm{W}=$ winter visitor.

Table 3. Some communally occurring birds of Bahawalpur district.

\begin{tabular}{ccc}
\hline Scientific name & Order & Frequency of occurrence \\
\hline Tachybaptus ruficollis & Podicipediformes & $\mathrm{F}$ \\
Podiceps grisegena & Podicipediformes & $\mathrm{F}$ \\
Podiceps cristatus & Podicipediforme & $\mathrm{W}$ \\
Podiceps auritus & Podicipediformes & $\mathrm{F}$ \\
Gavia arctica & Gaviformes & $\mathrm{W}$ \\
Gavia immer & Gaviformes & $\mathrm{W}$ \\
Parus major & Passeriformes & $\mathrm{W}$ \\
Pycnonotus cafer & Passeriformes & $\mathrm{F}$ \\
Copsychus saularis & Passeriform & $\mathrm{W}$ \\
Ardeola greyii & Ciconiformes & $\mathrm{N}$ \\
Egretta garzetta & Ardeidae & $\mathrm{W}$ \\
Pycnonotus cafer & Passeriformes & $\mathrm{N}$ \\
Psittacula krameri & Psittacidae & $\mathrm{N}$ \\
\hline
\end{tabular}

$\mathrm{F}=$ frequent; $\mathrm{N}=$ native; $\mathrm{W}=$ winter visitor.

Table 4. Comparison of food preferences of male blue rock pigeons in location Rawalpindi in the the year-wise seasons.

\begin{tabular}{|c|c|c|c|c|c|c|c|c|c|c|c|}
\hline \multirow{2}{*}{\multicolumn{2}{|c|}{ Food Crops }} & \multicolumn{6}{|c|}{ Seasonal variations for food crops } & \multicolumn{2}{|c|}{ Component-1 } & \multicolumn{2}{|c|}{ Component-2 } \\
\hline & & Spring & Summer & Fall & Winter & Mass & $\overline{\text { Quality }}$ & Corr. & Contr. & Corr. & Contr. \\
\hline \multicolumn{2}{|c|}{ Brassica campestris } & 0.312 & 0.118 & 0.170 & 0.401 & 0.143 & 0.987 & 0.751 & 0.281 & 0.235 & 0.206 \\
\hline \multicolumn{2}{|c|}{ Carthamus oxyacantha } & 0.560 & 0.189 & 0.046 & 0.205 & 0.016 & 0.327 & 0.015 & 0.001 & 0.313 & 0.027 \\
\hline \multicolumn{2}{|l|}{ Hordeum vulgare } & 0.327 & 0.436 & 0.188 & 0.048 & 0.184 & 0.983 & 0.710 & 0.141 & 0.273 & 0.127 \\
\hline \multicolumn{2}{|c|}{ Pennisetum glaucum } & 0.280 & 0.587 & 0.123 & 0.011 & 0.061 & 0.992 & 0.949 & 0.173 & 0.043 & 0.018 \\
\hline \multicolumn{2}{|l|}{ Sorghum vulgaris } & 0.287 & 0.513 & 0.000 & 0.200 & 0.160 & 0.953 & 0.543 & 0.190 & 0.410 & 0.336 \\
\hline \multicolumn{2}{|l|}{ Triticum aestivum } & 0.396 & 0.253 & 0.201 & 0.149 & 0.169 & 0.244 & 0.077 & 0.004 & 0.168 & 0.020 \\
\hline \multicolumn{2}{|l|}{ Zea mays } & 0.267 & 0.202 & 0.306 & 0.224 & 0.192 & 0.949 & 0.654 & 0.135 & 0.295 & 0.142 \\
\hline \multicolumn{2}{|l|}{ Unidentified plants } & 0.056 & 0.176 & 0.512 & 0.256 & 0.016 & 0.746 & 0.355 & 0.039 & 0.392 & 0.101 \\
\hline \multicolumn{2}{|c|}{ Unidentified animals } & 0.591 & 0.000 & 0.135 & 0.275 & 0.022 & 0.504 & 0.402 & 0.037 & 0.102 & 0.022 \\
\hline \multicolumn{2}{|l|}{ Grits } & 0.312 & 0.340 & 0.163 & 0.185 & 0.038 & 0.866 & 0.723 & 0.001 & 0.143 & 0.000 \\
\hline \multirow{2}{*}{$\begin{array}{l}\text { Seasons and food } \\
\text { crops }\end{array}$} & Mass & 0.320 & 0.315 & 0.177 & 0.187 & \multirow{2}{*}{\multicolumn{6}{|c|}{$\begin{array}{l}\text { Corr. stands for Correlation Coefficient } \\
\text { Contr. stands for Contribution of Component }\end{array}$}} \\
\hline & Quality & 0.054 & 0.955 & 0.988 & 0.944 & & & & & & \\
\hline \multirow[t]{2}{*}{ Component-1 } & Corr. & 0.001 & 0.954 & 0.355 & 0.640 & & & & & & \\
\hline & Contr. & 0.000 & 0.537 & 0.153 & 0.310 & & & & & & \\
\hline \multirow[t]{2}{*}{ Component-2 } & Corr. & 0.054 & 0.000 & 0.632 & 0.304 & & & & & & \\
\hline & Contr. & 0.015 & 0.000 & 0.639 & 0.345 & & & & & & \\
\hline
\end{tabular}


'mass index', it was apparent that, yet again, the highest proportion (19.2\%) was shown by Zea mays (18.4\%) by the Pennisetum glaucum, while the minimum $(3.80 \%)$ was contributed by the grits. The quality column indicated the 'row inertia' as described by the two components of food abundance and also the information which was present in each of the two components (Table 4). Of the rows, Brassica campestris and Pennisetum glaucum depicted the percentage of food abundance $(0.982 \%$ and $0.992 \%)$, and the unidentified plants $(0.160)$ were ranked lowest proportions in the rock-dove. Of the correlative index of the male pigeons in Rawalpindi (based on food abundance), apparently the component-I remained highest for the inertial percentage proportions (Pennisetum glaucum 94.9 and Brassica campestris 75.1). Maximum contribution to first component was again that of B.campestris (28.1\%) and poorest (1.0) from the Carthamus oxyacantha. In the second component, high correlation (41.0\%) was represented by the Sorghum vulgaris, and the predominant contribution occurred, yet again was obtained from $S$. vulgaris (33.6\%). Food preferences for the females regarding the same designated habitats, depicted seasonal consumption of food crops, Carthamus oxyacantha remained highest (50.4\%) in spring, while Triticum aestivum (0.364) and Hordeum vulgare (0.333) were the least of all (Table 5). For the remaining seasons, maximum predilection of the rock-dove was Sorghum vulgare (52.8\%), Zea mays (33.4\%) and Brassica campestris $(38.0 \%)$. Of the mass proportions, maximum (17.5\%) were of Hordeum vulgare and Zea mays, and the grits (3.9\%) remained lowest. For quality proportions, yet again, Zea mays (99.6\%) were maximum and closely followed by Pennisetum glaucum (95.8\%), Brassica campestris (95.3\%) and Sorghum vulgaris (91.4\%). For the correlation, apparently, Z. mays (98.9\%) remained highest and C. oxyacanta $(0.8 \%)$ being the lowest.

\subsection{Faisalabad}

For Faisalabad, feeding regimes of blue-rock pigeon were also assessed for both the genders in four seasons. Figure 1 describes food preference for the males with maximum depredations (65.4\%) on Carthamaus oxyacantha, (58.0\%) for Pennisetum glaucum, (45.0\%) on Sorghum vulgaris and the minimum (0.0) for unidentified and plant materials. Nonetheless, for spring, fall and winter, highest feeding proportions of rock-dove were for Triticum aestivum (39.8\%), Zea mays (38.9\%) and Brassica campestris (50.0\%). Similarly, the mass index (MI) remained highest (17.7) yet again, for $Z$. mays and lowest (0.009) for B. campestris, whereas, the 'row inertia' remained highest (97.9) for unidentified plant materials, while (97.5) and least (0.14) for T. aestivum. On the basis of food abundance correlation, peak values were of Brassica and P. glaucum (0.966 and 0.757), and lowest of un-identified plant materials (0.095). Highest food contribution (0.076) was furnished by $B$. campestris (0.49) and P. glaucum (0.28); while least proportions were that of the grits $(0.004)$. For the female rock-dove, information is provided in Figure 2. Apparently, maximum percentage of food composition in all four seasons viz. spring, summer, fall and winter were of Hordeum vulgare (40.4\%), Pennisetum glaucum (56.5\%), Zea mays (46.1\%) and Brassica campestris $(52.4 \%)$ respectively. Highest mass index $(0.175)$ remained for Triticum aestivum and 'row inertia' (0.99) of Z. mays. Maximum correlation for food abundance ( 0.93 ) was yet again for $B$. campestris with the food contribution factor (0.46) yet again for Brassica species.

\subsection{Bahawalpur}

The region of Bahawalpur comprises the Cholistan desert which finally incorporates in the large Thar Desert. It is a major cotton growing region of Pakistan. Observations regarding the food efficiency of the male blue-rock pigeon

Table 5. Determination of food preferences of female blue rock pigeons in location Rawalpindi for the yearly seasons.

\begin{tabular}{|c|c|c|c|c|c|c|c|c|c|c|c|}
\hline \multirow{2}{*}{\multicolumn{2}{|c|}{ Food items }} & \multicolumn{6}{|c|}{ Seasonal variations for different food crops } & \multicolumn{2}{|c|}{ Component-1 } & \multicolumn{2}{|c|}{ Component-2 } \\
\hline & & Spring & Summer & Fall & Winter & Mass & Quality & Corr. & Contr. & Corr. & Contr. \\
\hline \multicolumn{2}{|l|}{ Brassica campestris } & 0.222 & 0.195 & 0.204 & 0.380 & 0.136 & 0.953 & 0.449 & 0.122 & 0.505 & 0.238 \\
\hline \multicolumn{2}{|l|}{ Carthamus oxyacantha } & 0.504 & 0.167 & 0.018 & 0.311 & 0.017 & 0.685 & 0.008 & 0.001 & 0.677 & 0.081 \\
\hline \multicolumn{2}{|l|}{ Hordeum vulgare } & 0.333 & 0.474 & 0.143 & 0.051 & 0.175 & 0.982 & 0.827 & 0.228 & 0.155 & 0.074 \\
\hline \multicolumn{2}{|l|}{ Pennisetum glaucum } & 0.136 & 0.337 & 0.463 & 0.064 & 0.091 & 0.958 & 0.161 & 0.053 & 0.797 & 0.452 \\
\hline \multicolumn{2}{|l|}{ Sorghum vulgaris } & 0.279 & 0.528 & 0.000 & 0.193 & 0.145 & 0.914 & 0.763 & 0.290 & 0.150 & 0.099 \\
\hline \multicolumn{2}{|l|}{ Triticum aestivum } & 0.364 & 0.303 & 0.203 & 0.129 & 0.168 & 0.189 & 0.120 & 0.008 & 0.068 & 0.008 \\
\hline \multicolumn{2}{|l|}{ Zea mays } & 0.239 & 0.181 & 0.334 & 0.246 & 0.175 & 0.996 & 0.989 & 0.217 & 0.007 & 0.003 \\
\hline \multicolumn{2}{|l|}{ Unidentified plants } & 0.103 & 0.308 & 0.306 & 0.283 & 0.029 & 0.485 & 0.483 & 0.022 & 0.002 & 0.000 \\
\hline \multicolumn{2}{|l|}{ Unidentified animals } & 0.382 & 0.000 & 0.258 & 0.359 & 0.025 & 0.805 & 0.552 & 0.057 & 0.253 & 0.045 \\
\hline \multicolumn{2}{|l|}{ Grits } & 0.276 & 0.369 & 0.166 & 0.189 & 0.039 & 0.907 & 0.777 & 0.003 & 0.131 & 0.001 \\
\hline \multirow{2}{*}{$\begin{array}{l}\text { Seasons versus food } \\
\text { crops }\end{array}$} & Mass & 0.276 & 0.325 & 0.210 & 0.189 & Corr & $\operatorname{tands} \mathrm{f}$ & Corre & tion $\mathrm{Co}$ & efficient & \\
\hline & Quality & 0.334 & 0.902 & 1.000 & 0.964 & & stands & & bution & of Comp & onent \\
\hline \multirow[t]{2}{*}{ Component-1 } & Corr. & 0.254 & 0.851 & 0.632 & 0.342 & & & & & & \\
\hline & Contr. & 0.046 & 0.389 & 0.394 & 0.172 & & & & & & \\
\hline \multirow[t]{2}{*}{ Component-2 } & Corr. & 0.080 & 0.050 & 0.368 & 0.621 & & & & & & \\
\hline & Contr. & 0.025 & 0.040 & 0.396 & 0.539 & & & & & & \\
\hline
\end{tabular}




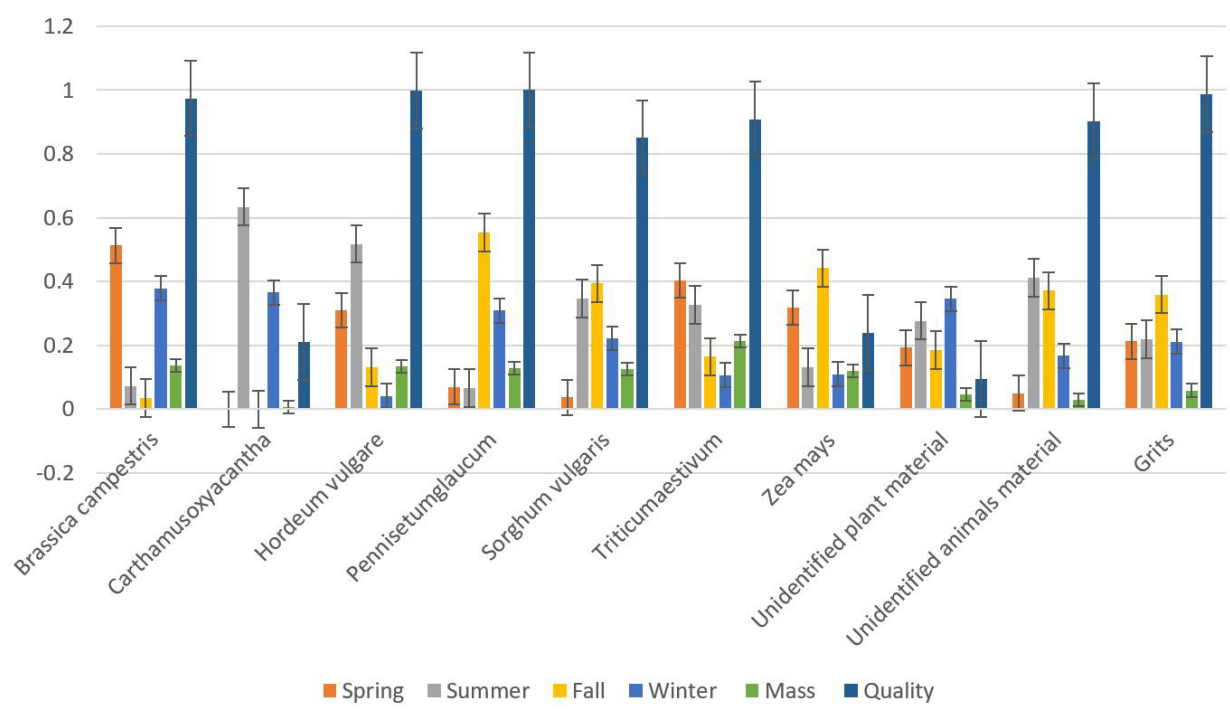

Figure 1. Comparison of the feeding profiles in the various food resources of the male blue rock pigeon in Faisalabad district.

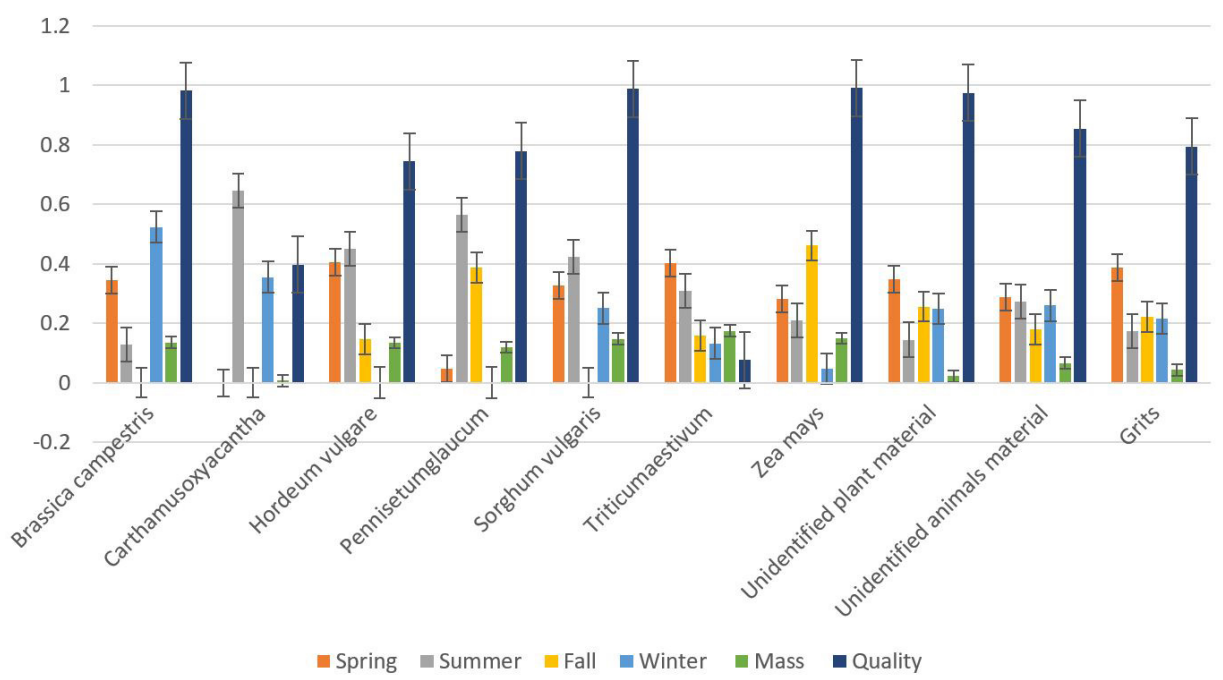

Figure 2. Feeding proportions comparison of female blue rock pigeon in Faisalabad in the yearly season.

here for the yearly seasons indicated (Figure 3) that, in spring, highest proportions were of Brassica campestris (45.6\%), Triticum aestivum (40.8\%) and Zea mays (31.8\%). In the summer, it were Carthamaus oxyacanta $(62.5 \%)$, and was closely followed by Hordeum vulgare (50.6\%), Triticum aestivum (32.5\%) and Sorghum vulgaris (31.3\%). For the fall and winter seasons respectifvely, maximum depredations were recorded for Pennisetum glaucum (55.6\%), and were comparable to that of Zea mays (44.6\%) and Sorghum vulgaris (42.5\%); Brassica campestris (39.8\%), Cathamus oxyacanta (37.5) and Pennisetum glaucum $(32.7 \%)$, respectively. Similarly, maximum mass index (MI) was for T. aestivum, while lowest (0.044) was that for unidentified plant materials). For the row-wise quality intertia, (P. glaucum)), indicated highest proportion followed closely by $H$. vulgare $(0.998)$ and that of $B$. campestris (0.977), while P. glaucum (1.00) provided the highest ratio of food abundance for the correlation (0.828) for P. glaucum, followed by ( 0.386$)$ by the Sorghum vaulgaris. Maximum contribution factor (0.965) was recorded yet again, for P. glaucum (0.865), for T. aestivum and (0.558) for Sorghum vulgaris. For the female rock-dove of the same habitat, maximum foraging efficiencies during all the seasons were depicted by $B$. campestris $(51.3 \%)$ and later by $T$. aestivum $(40.3 \%)$ and $H$. vulgare $(31.0 \%)$. For summer season, maximum food preference was indicated 
by $C$. oxyacantha $(63.4 \%)$, and subsequently $(51.8 \%)$ by H. vulgare and (34.7\%) by Sorghum vulgaris. Similarly, maximum food predilection during fall and winter were of P. glaucum (55.4\%), ranked next by Z. mays (44.2\%) and lowest $(0.00)$ by the $C$. oxyacantha; maximally by the B. campestris $(37.9 \%)$, C. oxyacantha $(36.6 \%)$ and least by H. vulgare $(0.041 \%)$. Maximum mass index (MI) was for Triticum aestivum (21.4) which was followed by (13.6) by Brassica campestris. Row-inertial quality was maximum (1.00) for Pennisetum glaucum and was sequentially followed by Hordeum vulgare (0.999), Brassica campestris (0.974), Triticum aestivum (0.909) and Sorghum vulgaris (0.850) which represented their maximum food predilection by the rock-dove. Finally, the correlation coefficient and contribution factors for the female blue rock pigeon were by Pennisetum glaucum (0.94) and (0.41) (Figure 4).

Data on the present study on feeding patterns of the rock-dove species in the three study areas viz. Rawalpindi,
Faisalabad and Bahawalpur, Pakistan indicated that the diet of both the genders comprised varied food items. It was evident from the detailed survey of roosts that invariably majority of these were present fairly close to the various food crops which resulted in frequent pigeon movement patterns in the diurnal hours, with little impacts on their energy budgets during the visitations. Of the four seasons, spring was most profitable for the both male and female pigeons, followed by summer, fall and winter. Of the varied food resources, Zea mays, Hordeum vulgare, Brassica campestris and Triticum aestivum were predominantly fed by the blue-rock pigeon, while other plantations were consumed in low and comparable proportions (Tables 4 and 5; Figures 1, 2, 3 and 4). Contribution of unidentified plant, animals and grits were of lower proportions. Of all three locations, region of Rawalpindi, situated at the Pothawar Plateu, at some elevation than Faisalabad and the deserted Bahawalpur; however, no wide variations for food

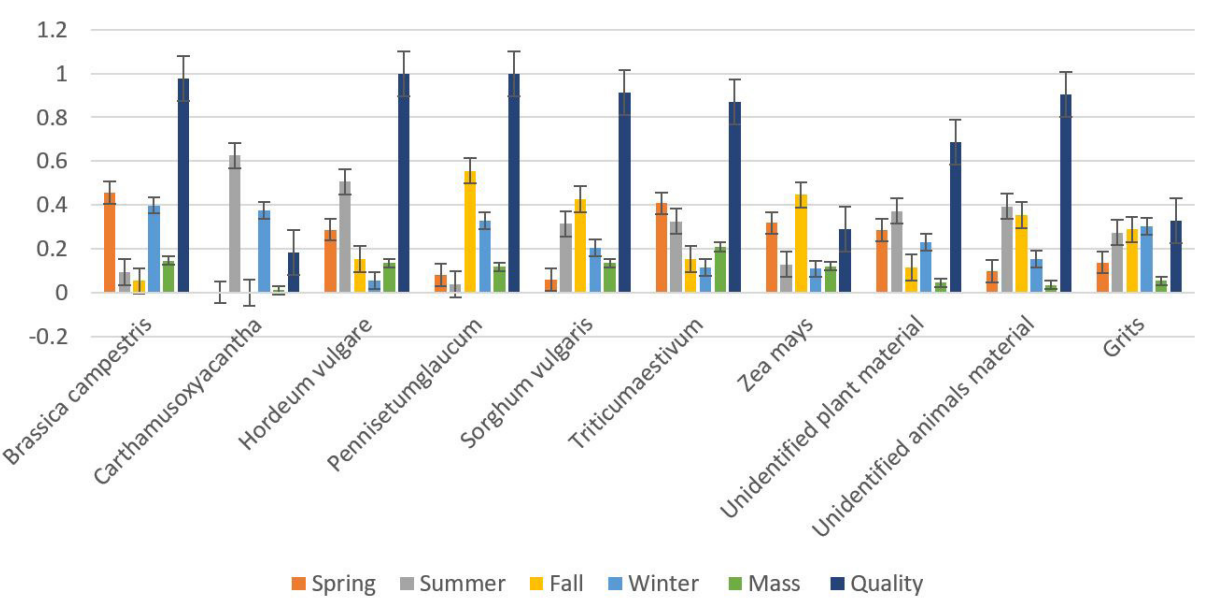

Figure 3. Occurrence of varied food crops in Bahawalpur district for the male blue rock pigeon.

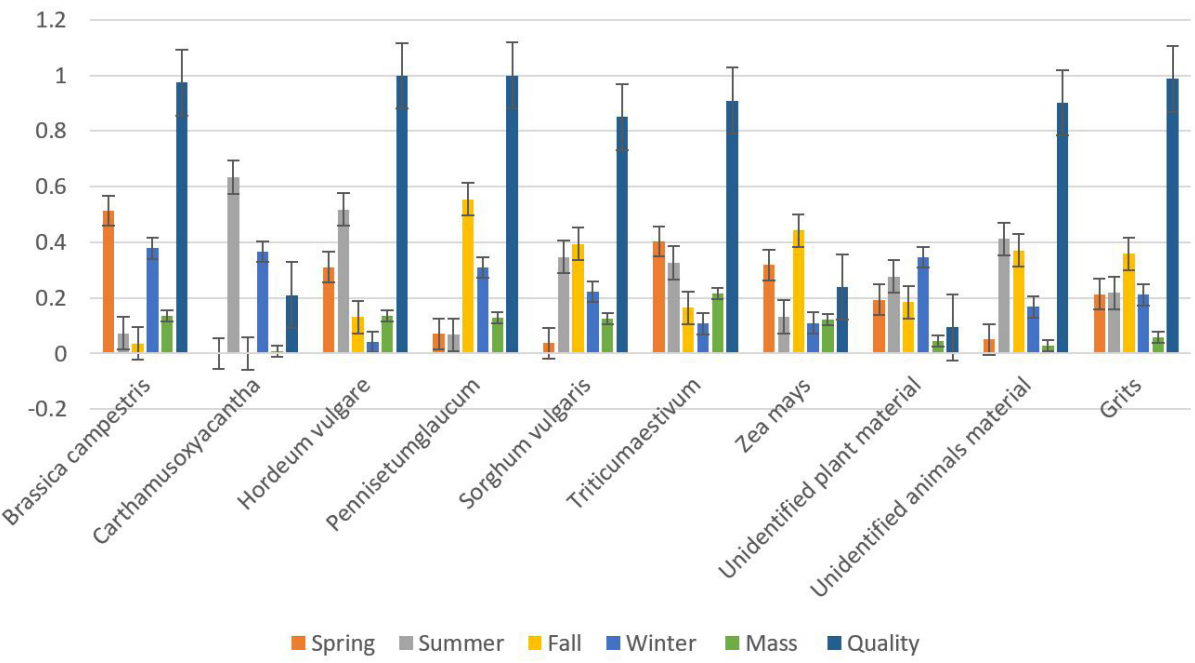

Figure 4. Feeding behavior recorded for female pigeons in Bahawalpur during the year. 
predilection were recorded. The data also reports on the mass index (MI) and food quality (FQ) values for all the three sites. Overall, the mass index remained fairly high (19.2\%) for Zea mays and lowest $(0.038 \%)$ for unidentified animals which were extracted in its food proportions in Rawalpindi. Similarly, maximum food quality $(94.9 \%)$ was for Pennisetum glaucum and least $(0.015 \%)$ for Carthamus oxyacantha in the same habitat, whereas, the highest correlation with regard to food resources was yet again, for Pennisetum glaucum and minimum $(0.015 \%)$ for Carthamus oxyacantha (Table 4). Maximum and minimum contribution components (CC) for the male rock-dove in Rawalpindi were $(28.0 \%)$ and $(0.001 \%)$ for Brassica campestris and grits respectively.

For the female rock-dove, highest consumed food crop in spring (50.4\%) was Carthamus oxyacantha, and lowest $(0.10 \%)$ were the unidentified plant materials. Situation for summer, fall and winter seasons depicted $(52.8 \%, 46.3 \%$ and $38.0 \%$ ) for Sorghum vulgare, Pennisetum glaucum and

Brassica campestris respectively (Table 5). For the mass index, food quality, maximum correlation and contributing components $(0.175 \%, 0.996 \%, 0.989 \%$ and $0.29 \%)$ for the Zea mays each and that of Sorghum vulgaris. The data also indicates varied trends for the food preferences for Faisalabad and Bahawalpur; nonetheless Zea mays, Hordeum vulgare, Pennisetum glaucum and Brassica campestris remained intensively depredated food items regarding both sexes of the rock-dove (Figures 1, 2, 3 and 4).

As evinced from the present study, the pigeon diet largely remained idiosyncratic for three major regions of Punjab, Pakistan. As has also been reported by (Moon and Zeigler, 1979; Giraldeau and Lefebvre, 1985; Biedermann et al., 2012), rock-dove food also possesses variations even among nearby habitats. Although, Zea mays happened to be the major food for the pigeon, incorporation of Hordeum vulgare, Brassica campestris, Pennsietun glaucum and Sorghum vulgare were also frequented among three habitats. Such similarities have also been reported by Moon and Zeigler (1979). According to them, pigeons mostly preferred the maize grains, but such granules of sufficiently large size were rebuffed by them, possibly not able to masticate (Shettleworth, 1993). Populations of the urban pigeons appear to depend on the 'refuse foods' resulting from the human spills like the bread and seeds at various sites, therefore, encouraging their population's manifolds (Sol and Lefebvre, 2000). It was evident from this study also that despite long distance apart among three sites, more or less feeding habits and mass index, food quality, correlative values and contribution components did not seem to vary diversely due to similarities of food resources. Murton and Westwood (1966) have suggested that both genders of the blue-rock pigeon largely relied on occurrence of bread, nuts and currants in the urban avenues. Similar findings reported by (Biedermann et al., 2012) regarding blue-rock pigeon indicated presence of sunflower meal, sorghum, maize granules and dried peanuts, therefore, preferring foods comprising fats than the carbohydrates viz. sorghum and corns.

\section{Conclusions}

On the basis of the present study, it was concluded that, the blue-rock pigeon was important bird in the various agro-ecosystems of Punjab, Pakistan with the diversified feeding habits and perhaps proves tenacious to the existing food crops, particularly at the seedling stages. Moreover, as majority of pigeon roosts and nests can occur closely to the feeding resources (crops, stored grains and human habitations), they can manage intermittent visitations in both rural and urban environments, therefore, incurring the considerable economic losses. Larger populations of feral pigeons also regarded threats to cause potential infections to both poultry and humans, particularly in the clumped conditions.

\section{References}

ANGOLD, P., SADLER, J.P., PEATY, L., WHITEHEAD, J.W.R., BALE, J. and PULIN, A., 2001. Biodiversity in urban habitat patches. Birmingham: University of Birmingham, pp. 2-3.

BALDACCINI, N.E., 1996. Diminuzione del numero di colombi di città a Bolzano in seguito an interventi di controllo. Supplemento alle Ricerche di Biologia della Selvaggina, vol. 17, pp. 102-104.

BALDACCINI, N.E., GIUNCHI, D., MONGINI, E. and RAGIONIERI, L., 2000. Foraging flights in wild rock doves (Columba l. livia): a spatio-temporal analysis. The Italian Journal of Zoology, vol. 67, no. 4, pp. 371-377. http://dx.doi. org/10.1080/11250000009356342.

BALLARINI, G., BALDACCINI, N.E. and PEZZA, F., 1989. Colombi in città: aspetti biologici, sanitari e giuridici: metodologie di controllo. Bologna: Istituto Nazionale di Biologia della Selvaggina.

BEVAN, R.D.R., 1990. The costs of feral pigeons. In: Proceedings of a Symposium, 1990, London. London: British Ornithological Union, vol. 3, pp. 73-79.

BIEDERMANN, T., GARLICK, D. and BLAISDELL, A.P., 2012. Food choice in the laboratory pigeon. Behavioural Processes, vol. 91, no. 1, pp. 129-132. http://dx.doi.org/10.1016/j. beproc.2012.06.005. PMid:22750307.

BURGMAN, M.A. and LINDENMEYER, D.B., 1998. Conservation for Australian environment. Sydney: Beatty and Sons Survey, pp. 128-145.

CANOVER, M.R., 2002. Resolving human-wildlife conflicts: the science of wildlife damage management. Boca Raton: Lewis Publishers, pp. 28-31.

CLEARY, E.C., DOLBEER, R.A. and WRIGHT, S.E., 2006. Wildlife strikes to civil aircraft in the United States, 1990-2005. Lincoln: University of Nebraska, pp. 48-55.

CURTIS, L., LEE, B.S., CAI, D., MOROZOVA, I., FAN, J.L., SCHEFF, P., PERSKY, V., EINODER, C. and DIBLEE, S., 2002. Pigeon allergens in indoor environments: a preliminary study. Allergy, vol. 57, no. 7, pp. 627-631. http://dx.doi.org/10.1034/j.13989995.2002.03405.x. PMid:12100304.

DOLBEER, R.A., 1998. Evaluation of shooting and falconry to reduce bird strikes with aircraft at John F. Kennedy international airport. Starra Lesna: International Bird Strike Committee, pp. 14-18. 
DOLBEER, R.A., WRIGHT, S.E. and CLEARY, E.C., 2000. Ranking the hazard level of wildlife species to aviation. Wildlife Society Bulletin, vol. 28, pp. 372-378.

FEARE, C.J., 1991. Control of bird pest populations. In: C.M. PERRINS, J.D. LEBRETON and G.J. HIRONS, eds. Bird population studies. London: Oxford University Press.

GAllo, M.G., CABELI, P. and VIDOTTO, V., 1989. Sulla presenza di lieviti patogeni nelle feci di Colombo torraiuolo (Columba livia, Gmelin 1789, forma urbana) della città di Torino. Parasitology, vol. 31, pp. 207-212.

GIRALDEAU, L.A. and LEFEBVRE, L., 1985. Individual feeding preferences in feral groups of rock-doves. Canadian Journal of Zoology, vol. 63, no. 1, pp. 189-191. http://dx.doi. org/10.1139/z85-028.

GOODWIN, D., 1983. Pigeons and doves of the world. 3rd ed. New York: Cornell University Press.

HAAG-WACKERNAGEL, D., 1991. Population density as a regulator of mortality among eggs and nestlings of feral pigeons (Columba livia) in Basil, Switzerland. Polish Science Publishing, vol. 2, pp. 21-31.

HAAG-WACKERNAGEL, D., 1993. Street pigeons in Basel. Nature, vol. 361, no. 6409, pp. 200. http://dx.doi.org/10.1038/361200a0.

HAAG-WACKERNAGEL, D., 1994. Die strassentaube: die geschichteeiner mensch-tier-beziehung. Schweizer Tierschutz, Du und die Natur, vol. 3, pp. 4-29.

HAAG-WACKERNAGEL, D., 2000. Comparison between two censuses of Feral Pigeon Columba livia var. from Barcelona: an evaluation of seven years of control by killing. Folia Zoologica, vol. 49, pp. 101-114.

HAAG-WACKERNAGEL, D. and GEIGENFEIND, I., 2008. Protecting buildings against feral pigeons. European Journal of Wildlife Research, vol. 54, no. 4, pp. 715-721. http://dx.doi. org/10.1007/s10344-008-0201-z.

HAAG-WACKERNAGEL, D. and MOCH, H., 2004. Health hazards posed by feral pigeon. Infectious Diseases, vol. 48, pp. 307-313.

HAAG-WACKERNAGEL, D., INDERWILDI, E. and NAGEL, P., 2006. Spatio-temporal use of the urban habitat by feral pigeons (Columba livia). Behavioral Ecology and Sociobiology, vol. 60, no. 2, pp. 242-254. http://dx.doi.org/10.1007/s00265-006-0162-8.

HETMANSKI, T., BOCHENSKI, M., TRYJANOWSKI, P. and SKÓRKA, P., 2010. The effect of habitat and number of inhabitants on the population sizes of feral pigeons around towns in northern Poland. European Journal of Wildlife Research, vol. 57, no. 3, pp. 421-428. http://dx.doi.org/10.1007/s10344-010-0448-z.

JOHNSTON, R. and JANIGA, M., 1995. The feral pigeons. London: Oxford University Press, 477 p.

KAUTZ, J.E. and MALECKI, R.A., 1991. Effects of harvest on feral rock dove survival, nest success and population size. Washington: U.S. Dept. of the Interior, Fish and Wildlife Service.

LEVER, C., 1987. Naturalized birds of the world. New York: Wiley.

MAAN, M.A. and CHAUDHRY, A.A., 2001. Wildlife diversity in Punjab. Pakistan Journal of Biological Sciences, vol. 1, no. 5, pp. 417-420. http://dx.doi.org/10.3923/jbs.2001.417.420.

MOON, R.D. and ZEIGLER, H.P., 1979. Food preferences in the pigeon (Columba livia). Physiology \& Behavior, vol. 22, no.
6, pp. 1171-1182. http://dx.doi.org/10.1016/0031-9384(79)902737. PMid:493392.

MURTON, R. and WESTWOOD, N., 1966. The foods of rockdoves and feral pigeon. Bird Study, vol. 13, no. 2, pp. 130-146. http://dx.doi.org/10.1080/00063656609476116.

PEDERSEN, K., CLARK, L., ANDELT, W.F. and SALMAN, M.D., 2006. Prevalence of shiga toxin-producing Escheretia coli and Salmonella enteric in rock-pigeons captured at Fort Collins, Colorado. Journal of Wildlife Diseases, vol. 42, no. 1, pp. 46-55. http://dx.doi.org/10.7589/0090-3558-42.1.46. PMid:16699148.

PIMENTAL, D., LACH, L., ZUNIGA, R. and MORRISON, D., 2000. Environmental and economic costs of non-indigenous species in the United States. Biomedical Science, vol. 50, pp. 53-65.

ROBERTS, J.J., 1991. Birds of Pakistan. London: Oxford University Press, $825 \mathrm{p}$.

SACCHI, R., GENTILLI, A., RAZZETTI, E. and BARBIERI, F., 2002. Effects of building features on density and flock distribution of feral pigeons Columba livia var. domestica in an urban environment. Canadian Journal of Zoology, vol. 80, no. 1, pp. 48-54. http://dx.doi.org/10.1139/z01-202.

SAINI, H.K. and TOOR, H.S., 1991. Feeding ecology and damage potential of feral pigeons (Columba livia) in an agricultural habitat. Le Gerfaut, vol. 81, pp. 195-206.

SEAMANS, T.W., BARRAS, S.C., BERHHARDT, B.F., BARRAS, S.C., BLACKWELL, B.F. and CEPAK, J.D., 2007. Comparison of two vegetation-height management practices for wildlife control at airports. Human-Wildlife Interactions., vol. 1, pp. 97-100.

SENAR, J.C., 1996. Bird census techniques for the urban habitat: a review. Controllo delle popolazioni ornitiche sinantropiche: "problemi e prospettive". ISS/WHO/FAO-CC/IZSTe/96.27. Rome: FAO, pp. 36-44.

SHETTLEWORTH, S.J., 1993. Varieties of learning and memory in animals. Journal of Experimental. Psychology: Animal Behavior Processes, vol. 19, pp. 5-14.

SIMS, E., 1979. The public life of street pigeon. London: Hutchinson.

SOL, D. and LEFEBVRE, L., 2000. Behavioural flexibility predicts invasion success in birds introduced to New Zealand. Oikon, vol. 90, no. 3, pp. 599-605. http://dx.doi.org/10.1034/j.16000706.2000.900317.x.

SOL, D. and PRICE, T.D., 2008. Brain size and diversification of body size in birds. American Naturalist, vol. 172, no. 2, pp. 170-177. http://dx.doi.org/10.1086/589461. PMid:18598187.

SOL, D. and SENAR, J., 1995. Urban pigeon populations: stability, home range, and the effect of removing individuals. Canadian Journal of Zoology, vol. 73, no. 6, pp. 1154-1160. http://dx.doi. org/10.1139/z95-137.

SOLDATINI, C., MAINARDI, D., EMILIO BALDACCINI, N. and GIUNCHI, D., 2006. A temporal analysis of the foraging flights for feral pigeons (Columba livia) from three Italian cities. The Italian Journal of Zoology, vol. 73, no. 1, pp. 83-92. http:// dx.doi.org/10.1080/11250000500502210.

SOSSINKA, R., 1982. Domestication in birds. Avian Biology, vol. 6, pp. 373-403. http://dx.doi.org/10.1016/B978-0-12-2494062.50016-2. 
STEEL, R.G.D., TORRIE, T.H. and DICKEY, D.A., 1997. Principles and procedures of statistics: a biometrical approach. New York: McGraw Hill.

VAN NIEKERK, J.H. and VAN GINKEL, C.M., 2004. The feeding behaviour of pigeons and doves on sown grain crops on the South African Highveld. Journal of African Ornithology, vol. 75, no. 1-2, pp. 39-43. http://dx.doi. org/10.2989/00306520409485410.
WILLIAMS, D.E. and CORRIGAN, R.M., 1994. The handbook: prevention and control of wildlife damage. Nebraska: University of Nebraska, 740 p.

YOUNAS, M. and YAQOOB, M., 2005. Feed resources of livestock in the Punjab. Pakistan. Lives Research for Rural Development, pp. 18-20.

ZUCCONI, S., GALAVOTTI, S. and DESERTI, R., 2003. I colombi in ambiente urbano: sintesi del progetto di- ricerca Nomisma. Disinfestazione, vol. 3, pp. 9-21. 